\section{Plant Growth Regulators Affect the Development of Both Corms and Cormels in Gladiolus}

\author{
Raja Ram ${ }^{1}$, Debasish Mukherjee ${ }^{2}$, and Sandeep Manuja ${ }^{3}$ \\ Floriculture Division, Institute of Himalayan Bioresource Technology, \\ Palampur-176 061, India
}

Additional index words. Gladiolus sp., vegetative propagation, cultivar, sprouting

\begin{abstract}
The effects of $\mathrm{BA}$, ethephon, and $\mathrm{GA}_{3}$ on freshly harvested cormels of three cultivars of Gladiolus sp. were studied for 3 years. The treatment with $400 \mathrm{mg} \cdot \mathrm{L}^{-1}$ ethephon significantly reduced the dormancy period by 17.5 days as compared to control, while BA and $\mathrm{GA}_{3}$ were found to be less effective. Among all treatments, ethepon at $400 \mathrm{mg} \cdot \mathrm{L}^{-1}$ was found to be the most effective in altering the days to sprout, sprouting percentage, corm size and production and development of cormels. While $\mathbf{G A}_{3}$ at $100 \mathrm{mg} \cdot \mathrm{L}^{-1}$ increased growth of corms and cormels, BA at $25 \mathrm{mg} \cdot \mathrm{L}^{-1}$ increased growth of corms and cormels. BA at $25 \mathrm{mg} \cdot \mathrm{L}^{-1}$ only influenced the sprouting percentage of cormels. Along with reducing the dormancy period, the plant growth regulators stimulated growth and development of corms and cormels. Chemical names used: benzyladenine (BA); 2-chloroethylphosphonic acid (ethephon); gibberellic acid $\left(\mathrm{GA}_{3}\right)$.
\end{abstract}

The effectiveness of chemicals such as gibberellins (Arora etal., 1992), benzyladenine (Goo et al., 1998), ethephon (Suh, 1989) and methyl disulfide (Hosoki and Kubara, 1989) in breaking the dormancy of gladiolus (Gladiolus $\times$ grandiflora Hort.) corms and cormels has been studied extensively, treatment efficacy varies with chemical, cultivar, and other factors. Although cormels are more dormant than are corms, (Imanishi, 1981) their responses have not been thoroughly studied. Our objective was to find a suitable treatment to break the dormancy of cormels of three gladiolus cultivars and to determine their effects on the development of both corms and cormels.

\section{Materials and Methods}

The study was carried out over 3 years under open field conditions at the Floricultural Experimental Farm of the Institute of Himalayan Bioresource Technology, Palampur, situated in the foothills of Himalayas at an altitude of $\approx 1300 \mathrm{~m}$ and having a subtemperate type of climate. Average minimum and maximum monthly temperatures recorded over 3 years were $5.5^{\circ} \mathrm{C}$ (January) and $30.4{ }^{\circ} \mathrm{C}$ (June), respectively. Average minimum and maximum rainfall occurred in October $(27.8 \mathrm{~mm}$ ) and August (607.6 mm), respectively.

Three plant growth regulators, BA, ethephon, and $\mathrm{GA}_{3}$ were tested on fresh cormels of 'Friendship', 'Priscilla', and 'Video' within $15 \mathrm{~d}$ of harvest. The cormels were obtained by planting corms in June each year. BA was

Received for publication 29 Sept. 1999. Accepted for publication 8 Feb. 2001.

${ }^{1}$ Technical Officer.

${ }^{2}$ Scientist. To whom reprint requests should be addressed. E-mail address: dm_ihbt@yahoo.com

${ }^{3}$ Senior Research Fellow. tested at 25,50 , and $100 \mathrm{mg} \cdot \mathrm{L}^{-1}, \mathrm{GA}_{3}$ at 25 , 50 , and $100 \mathrm{mg} \cdot \mathrm{L}^{-1}$ and ethephon at 100,200 , and $400 \mathrm{mg} \cdot \mathrm{L}^{-1}$. The cormels $(0.75 \pm 0.1 \mathrm{~cm}$ in diameter and weighing $\approx 0.45 \mathrm{~g}$ ) were soaked in the solutions for $24 \mathrm{~h}$ (Arora et al. 1992; Hong and Goo, 1991) in the fourth week of January and planted in the field. The experiment was a factorial (plant growth regulator $\times$ cultivars) in a randomized completeblock design with three replications of 20 cormels each per replication. Cultural operations were as described by Anderton and Park (1989). Corms and cormels were harvested in October each year. Data (Table 1) were recorded for five cormels and corms in each replication. Days to sprouting was counted as days taken from sowing to the date the shoot emerges out of the soil.

To correct for heterogeneity of variance, data for percentage sprouting were transformed using angular (arc-sine) transformation. All data were analyzed by analysis of variance, and mean separation was accomplished by least significant difference (LSD), $P \leq 0.05$. Interactions between plant growth regulators and cultivars were nonsignificant and hence are not presented.

\section{Results and Discussion}

Days to sprouting. All chemicals regardless of concentration, significantly hastened sprouting of the cormels (Table 1), but 400 $\mathrm{mg} \cdot \mathrm{L}^{-1}$ ethephon was most effective. BA and $\mathrm{GA}_{3}$ were less effective than ethephon, as previously reported by Suh (1989).

The breaking of dormancy in gladiolus cormels has been linked to ethylene production. Ginzburg (1974) reported that ethephon promoted the growth of dormant cormels, and application of BA induced ethylene production (Ginzburg, 1973). 'Priscilla' cormels sprouted earliest, followed by 'Video' and 'Friendship'.
Percentage of sprouting. Of the 10 treatments, only ethephon at 200 and $400 \mathrm{mg} \cdot \mathrm{L}^{-1}$ and $\mathrm{BA}$ at $25 \mathrm{mg} \cdot \mathrm{L}^{-1}$ significantly increased percentage sprouting of cormels with 400 $\mathrm{mg} \cdot \mathrm{L}^{-1}$ ethephon being most effective and BA $25 \mathrm{mg} \cdot \mathrm{L}^{-1}$ being least effective. Promotion of sprouting of gladiolus cormels by ethephon was also noted by Ginzburg (1973) and other workers. Suh (1989) reported that ethephon (200 $\mathrm{mg} \cdot \mathrm{L}^{-1}$ ) promoted sprouting of 'Red Beauty' cormels while $\mathrm{BA}\left(20 \mathrm{mg} \cdot \mathrm{L}^{-1}\right)$ or $\mathrm{GA}_{3}$ (200 $\mathrm{mg} \cdot \mathrm{L}^{-1}$ ) had little effect. However, Goo et al., (1998) reported promotional effects of BA. Friendship sprouted best followed by 'Priscilla', sprouting of 'Video' was significantly lower.

Corm size. All treatments increased corm size with ethephon being most effective (Table 1). Suh and Kwack (1990) reported that when cormels were soaked in $20 \mathrm{mg} \cdot \mathrm{L}^{-1} \mathrm{BA}, 200$ $\mathrm{mg} \cdot \mathrm{L}^{-1} \mathrm{GA}_{3}$ or $200 \mathrm{mg} \cdot \mathrm{L}^{-1}$ ethephon for $6 \mathrm{~h}$, ethephon was most effective in increasing diameter. 'Friendship' produced significantly largest corms than did 'Priscilla' and 'Video'.

Weight of corms. All chemicals significantly increased corm weight with $200 \mathrm{mg} \cdot \mathrm{L}^{-1}$ ethephon and $400 \mathrm{mg} \cdot \mathrm{L}^{-1}$ ethephon having maximum effect. Hong and Goo (1991) reported that treatment with ethephon for $24 \mathrm{~h}$ increased corm weight and quality. Suh and Kwack (1990) observed that exposure to smoke (smoke contains ethylene) increased corm weight. Corm weight varied with cultivar, 'Friendship' producing the largest and 'Video' the smallest corms.

Cormel production. All treatments significantly increased cormel production, with maximum effects of $400 \mathrm{mg} \cdot \mathrm{L}^{-1}$ (138.6\% increase) and $200 \mathrm{mg} \cdot \mathrm{L}^{-1}$ ethephon $(90.3 \%) . \mathrm{GA}_{3}$ was more effective than BA. Halevy et al (1970) reported that ethephon increased cormel production by more than $100 \%$ in 'Spic and Span' and Magie (1971) noted a 90\% increase following ethephon treatment. Hong and Goo (1991) found $400 \mathrm{mg} \cdot \mathrm{L}^{-1}$ ethephon to be the best treatment for cormel production. Although Bhattacharjee (1984) reported that $\mathrm{GA}_{3}(10$ and $100 \mathrm{mg} \cdot \mathrm{L}^{-1}$ ) increased cormel production in 'Friendship', Arora et al. (1992) reported no significant effect of $\mathrm{GA}_{3}$ on cormel production. 'Friendship' produced the most cormels and 'Video' the least.

Weight of cormels. All chemicals significantly increased the weight of the cormels, maximum effect being obtained with 400 $\mathrm{mg} \cdot \mathrm{L}^{-1}$ ethephon $(200 \%)$ followed by 200 $\mathrm{mg} \cdot \mathrm{L}^{-1}$ ethephon $(104.8 \%)$. 'Friendship' cormels were significantly heavier than 'Priscilla' and 'Video' cormels.

In conclusion, ethephon at $400 \mathrm{mg} \cdot \mathrm{L}^{-1}$ was most effective treatment for many of the growth parameters including days to sprouting, percentage sprouting, corm diameter and cormel production and weight. Hong and Goo (1991) also noted that the best results were obtained with $400 \mathrm{mg} \cdot \mathrm{L}^{-1}$ ethephon. This effectiveness of ethephon in hastening sprouting may be due to breaking of apical dominance (Halevy et al, 1970), whereas its effects on corm and cormel production may have been due to an increase in assimilate mobilization, as the water poten- 
Table 1. Effects of plant growth regulators on sprouting of cormels and corm and cormel production of three gladiolus cultivars. Average data for 3 years $(1995,1996$, and 1997)

\begin{tabular}{|c|c|c|c|c|c|c|c|}
\hline \multirow[b]{2}{*}{ Treatment } & \multirow{2}{*}{$\begin{array}{l}\text { Concn } \\
\left(\mathrm{mg} \cdot \mathrm{L}^{-1}\right)\end{array}$} & \multirow{2}{*}{$\begin{array}{l}\text { No. of days } \\
\text { to sprouting }\end{array}$} & \multirow{2}{*}{$\begin{array}{c}\text { Sprouting } \\
(\%)^{\mathrm{z}}\end{array}$} & \multicolumn{2}{|c|}{ Corm } & \multicolumn{2}{|c|}{ Cormel } \\
\hline & & & & $\operatorname{Diam}(\mathrm{cm})$ & $\mathrm{Wt}(\mathrm{g})$ & No./plant & Wt $(\mathrm{g})$ \\
\hline \multicolumn{8}{|c|}{ Plant growth regulators } \\
\hline \multirow[t]{3}{*}{$\mathrm{BA}$} & 25 & $75.3^{y} b-d$ & $50.3(51.7) b c^{x}$ & $4.2 \mathrm{a}$ & $38.4 \mathrm{a}-\mathrm{c}$ & $17.4 \mathrm{bc}$ & $6.5 \mathrm{c}$ \\
\hline & 50 & $77.6 \mathrm{~d}$ & $47.4(47.0) b-d$ & $4.2 \mathrm{a}$ & $34.5 \mathrm{e}$ & $16.5 \mathrm{c}$ & $6.8 \mathrm{bc}$ \\
\hline & 100 & $75.7 \mathrm{~b}-\mathrm{d}$ & $44.7(46.0) \mathrm{d}$ & $4.3 \mathrm{a}$ & $36.5 \mathrm{bc}$ & $17.8 \mathrm{bc}$ & $7.3 \mathrm{bc}$ \\
\hline \multirow[t]{3}{*}{ Ethephon } & 100 & $73.0 \mathrm{~b}$ & $49.1(48.9) b-d$ & $4.6 \mathrm{a}$ & $42.3 \mathrm{ab}$ & $19.5 \mathrm{bc}$ & $7.8 \mathrm{bc}$ \\
\hline & 200 & $75.9 \mathrm{~b}-\mathrm{d}$ & $52.1(53.5) \mathrm{b}$ & $4.6 \mathrm{a}$ & $43.9 \mathrm{a}$ & $21.7 \mathrm{~b}$ & $8.6 \mathrm{~b}$ \\
\hline & 400 & $67.7 \mathrm{a}$ & $57.3(60.0) \mathrm{a}$ & $4.6 \mathrm{a}$ & $43.3 \mathrm{a}$ & $27.2 \mathrm{a}$ & $12.6 \mathrm{a}$ \\
\hline \multirow[t]{3}{*}{$\mathrm{GA}_{3}$} & 25 & $75.5 \mathrm{~b}-\mathrm{d}$ & $50.1(49.8) \mathrm{bc}$ & $4.3 \mathrm{a}$ & $36.9 \mathrm{bc}$ & $18.2 \mathrm{bc}$ & $6.9 \mathrm{bc}$ \\
\hline & 50 & $74.2 \mathrm{bc}$ & $46.6(44.8) \mathrm{cd}$ & $4.3 \mathrm{a}$ & $38.2 \mathrm{a}-\mathrm{c}$ & $19.3 \mathrm{bc}$ & $7.5 \mathrm{bc}$ \\
\hline & 100 & $76.7 \mathrm{~cd}$ & $48.1(49.3) b-d$ & $4.4 \mathrm{a}$ & $39.4 \mathrm{a}-\mathrm{c}$ & $20.2 \mathrm{bc}$ & $8.4 \mathrm{~b}$ \\
\hline Control & & $85.2 \mathrm{e}$ & $44.7(45.4) \mathrm{d}$ & $3.7 \mathrm{~b}$ & $27.1 \mathrm{~d}$ & $11.4 \mathrm{~d}$ & $4.2 \mathrm{~d}$ \\
\hline \multicolumn{8}{|l|}{ Cultivars } \\
\hline Friendship & & $80.6 \mathrm{~b}$ & $57.3(58.2) \mathrm{a}$ & $4.6 \mathrm{a}$ & $42.1 \mathrm{a}$ & 28.8 a & $9.0 \mathrm{a}$ \\
\hline Priscilla & & $67.5 \mathrm{a}$ & $51.0(54.7) \mathrm{b}$ & $4.2 \mathrm{~b}$ & $38.2 \mathrm{~b}$ & $15.4 \mathrm{~b}$ & $7.2 \mathrm{~b}$ \\
\hline Video & & $78.9 \mathrm{~b}$ & $38.9(36.6) \mathrm{c}$ & $4.0 \mathrm{~b}$ & $33.9 \mathrm{c}$ & $12.5 \mathrm{c}$ & $6.8 \mathrm{~b}$ \\
\hline
\end{tabular}

${ }^{\mathrm{z}}$ Analysis done after arcsin transformation of data.

${ }^{y}$ Means separation within columns and treatments (plant growth regulators, cultivar) by $\operatorname{LSD}_{0.05}$.

${ }^{x}$ Numbers in parentheses are the means for 3 years of nontransformed values.

tial of the corm (the competitive sink) remained high, aiding its growth and assimilate attraction (Robinson, 1983). Achhireddy et al. (1984) reported that the translocation of reserves to the sink in bean explants was promoted by ethephon, $\mathrm{GA}_{3}$, IAA, and BA. Ganyushkin (1993) also reported that Camposan (a trade formulation of $50 \%$ ethephon available in Russia) had a marked effect on tissue metabolism of gladiolus corms, but the extent of its influence on the physiological and biochemical processes depended on the time of treatment and especially on varietal characteristics.

\section{Literature Cited}

Achhireddy, N.R., R.C. Kirkwood, and G-van-den Berg. 1984. ${ }^{14} \mathrm{C}$-sucrose translocation in bean explants. Plant Growth Regulat. Bul. 12:5-7.

Anderton, E.W. and R. Park. 1989. Growing gladioli. 1st ed. Timber Press, Portland, Ore.

Arora, J.S., K. Singh, N.S. Grewal, and K. Singh.
1992. Effect of $\mathrm{GA}_{3}$ on cormel growth in gladiolus. Indian J. Plant Physiol. 35:202-206.

Bhattacharjee, S.K. 1984. The effects of growth regulating chemicals on gladiolus. Gartenbauwissenschaft 49:103-106.

Ganyushkin, E.V. 1993. Some physiological aspects in stimulating the development of gladioli corms with Camposan. Byulleten-GlavnogoBotanicheskogo-Sada. 167:102-107.

Ginzburg, C. 1973. Hormonal regulation of cormel dormancy in Gladiolus grandiflorus. J. Expl. Bot. 24:558-566.

Ginzburg, C. 1974. Studies on the role of ethylene in gladiolus cormel germination. Plant Sci. Lett. 2:133-138.

Goo, D.H., I.S. Park and K.W. Kim 1998. Effects of low temperature and growth regulators on dormancy breaking of gladiolus cormlets produced in vitro. J. Korean Soc. Hort. Sci. 39:479482.

Halevy, A.H., S. Ruth and S. Simchon. 1970. Effect of 2-chloroethanephosphonic acid (Ethrel) on health, dormancy and flower and corm yield of gladioli. J. Hort. Sci. 45:427-434.

Hong, Y.P. and D.H. Goo 1991. Studies on corm formation in Gladiolus gandavensis: The effects of plant growth regulators and physical treatments on sprouting of cormels and yield of gladiolus Res. Rpt. Korean Rural Dev. Adm. Hort. 33:125-130.

Hosoki T. and T. Kubara 1989. Breaking corm dormancy and accelerated flowering of gladiolus with methyl disulfide. HortScience. 24:968-971.

Imanishi, H. 1981. Disappearance of dormancy in gladiolus cormels stored dry at room temperature. J. Jpn. Soc. Hort. Sci. 50:92-99.

Magie, R.O. 1971. Effects of ethephon and benzimidazoles on corm and cormel production by gladiolus cormels. HortScience. 6: 351-352.

Robinson, M. 1983. Influence of abscisic acid and ethylene on assimilate distribution in Gladiolus grandiflora. Ann. Bot. 51:779-785.

Suh, J.K. 1989. Corm formation in gladiolus as influenced by dormancy breaking methods and cormel planting and corm harvesting dates. Proc. Korean Soc. Hort. Sci. 7:158-159.

Suh, J. K. and B.H. Kwack 1990. The corm formation of gladiolus as influenced by dormancy breaking methods, cormel planting and corm harvesting times. J. Korean Soc. Hort. Sci. 31:294-299. 